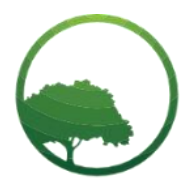

Research in Business \& Social Science

IJRBS VOL 10 NO 6 ISSN: 2147-4478

Business \& Social Science

IJRBS

Available online at www.ssbfnet.com

Journal homepage: https://www.ssbfnet.com/ojs/index.php/ijrbs

\title{
Investment climate for MSMEs towards a green economy
}

\section{Suparji}

Postgraduate Study Program in Law, Al Azhar University Indonesia, Al Azhar Grand Mosque Complex Jl. Sisingamangaraja, Kebayoran Baru, South Jakarta 12110 Jakarta, Indonesia

A R T I C L E I N F O
Article history:
Received 23 August 2021
Received in rev. form 16 Sep. 2021
Accepted 18 Sept 2021
Keywords:
Investment, MSME, Green Economy
JEL Classification:
O15

\section{Introduction}

Sustainable development is a development concept that has been applied for a long time in Indonesia, namely since 1970 where the concept of sustainable development that provides prosperity for present and future generations. balance is a key goal of sustainable development, namely balance in the economy, social and environment (Makmun, 2011) and to achieve this goal the government plays a role in the policy side that supports the three concepts as an interlinked helix.

Sri Adiningsih in Makmun said that the development carried out so far is more of short-term economic development oriented to GDP growth, without paying attention to the impact of environmental damage due to development and social inequality in society (Makmun, 2011).

MSMEs are the foundation of economic growth and as a supporter of the national economy of developing countries that are able to absorb up to $99 \%$ of the workforce, and are able to complement large industrial products in local and national markets. The development of MSMEs in Indonesia based on statistical data in 2013 states that the number of MSMEs is 57,895,721 with a workforce absorption of 114,144,082, the market capacity of MSMEs in regional and international markets is still relatively small, this can be seen from the contribution to the export value of only $9.29 \%$, so it is necessary to increase the capacity of MSMEs (Suparji, 2020).

* Corresponding author. ORCID ID: 0000-0001-5597-7095

(C) 2021 by the authors. Hosting by SSBFNET. Peer review under responsibility of Center for Strategic Studies in Business and Finance. https://doi.org/10.20525/ijrbs.v10i6.1360

\begin{abstract}
A B S T R A C T
Medium Enterprisesment has not provided the optimum portion of the support to Micro, Small \& as a supporter of the national economy of developing countries that are able to absorb up to $99 \%$ of the workforce, and are able to complement large industrial products in the local and local markets. In this research problem, what is the role of Islamic economics and the green economy in increasing MSMEs is the gap in accessing formal financial institutions in increasing capital, this is due to the weak management of MSMEs so that they are not bankable. Indonesia's financial inclusion as of 2019 analysis approach, this study analyzes data obtained from secondary sources. The type of research used is based on a normative juridical approach. Normative juridical research is legal research that examines library data, including legal principles and legislation. According to the type of norm study research, data acquisition is sourced from literature research related to the problem being studied, and interprets and reconstructs the statements contained in the legislation. The theory used is the theory of people's welfare. The results of this study can be a recommendation and can be used by and making MSMEs the frontline in supporting national economic growth so that Indonesia advances
\end{abstract}

(C) 2021 by the authors. Licensee SSBFNET, Istanbul, Turkey. This article is an open access article distributed under the terms and conditions of the Creative Commons Attribution (CC BY) license (http://creativecommons.org/licenses/by/4.0/). 
Wijayanto in Suparji said that MSMEs are institutions that can survive in the midst of a crisis. This can be seen from the monetary crisis in 1997-1998 which could absorb 85-107 million workers until 2012, from a total of 56,539,560 companies, there were $99.99 \%$ of companies in the MSME category, as well as during the COVID-19 pandemic at the beginning of 2019 until now (Suparji, 2020).

Indonesia's progress is largely supported by MSMEs which contribute $97 \%$ of employment, so that in total, the contribution of MSMEs to the national economy is $60 \%$, and accounts for $58 \%$ of total investment, and contributes to national exports by $14 \%$ of total exports. (Hartomo, 2020).

The desire to create prosperity for all people in the form of empowering the people's economy through strengthening MSMEs has been pledged since the beginning of the independence period and for that various development programs have been carried out, although until now there are still a group of people who are classified as poor. The not yet optimal success of economic development from regime to regime seems inseparable from the basic conception of development that has not fully prioritized the interests of people's economic empowerment (Azis, 2018).

In this research problem, what is the role of Islamic economics and green economy in increasing the capacity of MSMEs in order to advance the national economy. The role of MSMEs in progress in the national economy can be created if banking access (financial inclusion) and production efficiency and effectiveness can be increased in order to create competitive advantages in both local and global markets. One of the problems faced by MSMEs in increasing capacity is intense competition both on a local and global scale - they have to compete against imported products. Especially after the ratification of the world trade agreement (WTO) - the ratification of the WTO agreement based on Law no. 7/1994 and amendments to Law no. 17/2017 - as well as the Agreement on the implementation of the ASEAN Economic Community (MEA) which has been implemented since 2015 which creates consequences for implementing production effectiveness and efficiency in order to integrate with the global economy and to create competitive advantages (Orosz, 2017). In addition, MSMEs are faced with capital, so that the government's role is needed. Wimboh Santoso said that for that the government has rolled out an interest subsidy program for micro, small and medium enterprises (MSMEs) and has also placed government funds worth Rp. ). and the low ability to pay due to mismanagement that has the potential to go out of business, for that it is necessary to restructure their debt, for that the government through the OJK has issued regulations related to relaxation of debt payments, for that the government is obliged to provide concessions for debtors in banks and financial institutions through a restructuring program. Currently, the program has been implemented by around 100 banks with a total of 6.75 million debtors with a debit balance of Rp. 776.99 trillion, and has provided a financing stimulus through PEN (National Economic Recovery) so that MSMEs can compete globally. almost all countries do the same for their MSMEs so that they can continue to develop and improve their national economy (Alfitri, 2012). As is the case in Thailand, they have restructured the debt of their MSME businesses due to the impact of the crisis so that MSMEs will continue to survive and be able to continue paying their debts because their economy is supported by two-thirds of their GDP contributed by the MSME sector (Kurniawan, et al., 2015).

The limitation of the very cliche of MSMEs is the gap in accessing formal financial institutions in increasing capital, this is due to the weak management of MSMEs so that they are not bankable. Indonesia's financial inclusion as of 2019 is $76 \%$, and $25 \%$ of which has not been served by formal financial services, this can be seen from the capital structure of MSMEs in running their businesses, shown in the table below (Soesilo, 2007),

The government encourages the acceleration of digitalization of the financial sector in order to increase the capacity of MSMEs through facilities provided by the government through the National Economic Recovery (PEN) policy. The government seeks to help MSMEs with several incentives or assistance - providing interest subsidies, placing government funds in commercial banks for credit restructuring, guarantees for MSME loans, MSME final income tax borne by the government, investment financing to cooperatives through the Cooperative Revolving Fund Management Agency, Micro, Small and Medium Enterprises. and Medium (LPDBKUMKM), and productive presidential assistance or assistance for micro-enterprises (Hartomo, 2020).

The research method used is normative juridical, namely conceptualizing law as what is written in laws and regulations (law in books) or law as a rule or norm which is a benchmark for human behavior that is considered appropriate. This type of legal research is carried out by examining secondary data in the legal field as library data using deductive thinking methods. The approach used in answering the problem is to use a statutory approach and a conceptual approach. The legal approach is carried out by examining all laws and regulations related to the legal issues under study. This legal approach will open up opportunities for researchers to study whether there is consistency and conformity between one law and another. The conceptual approach is based on the views and doctrines that developed in the science of law, by studying the views and doctrines of the doctrine in the science of law. An understanding of these views and doctrines is the basis for researchers in building a legal argument in solving the issues at hand.

The procedure for collecting legal materials used in this research is a literature study, namely data collection by reading laws and regulations, official documents and literature that are closely related to the problems discussed. The legal materials are then analyzed and formulated as supporting legal materials in this research. Processing of legal materials is carried out deductively, namely drawing conclusions from a general problem to the concrete problems faced. The legal materials obtained in this study will be analyzed qualitatively using the deductive method, namely general data about the conception of legal materials in the form of legal principles, postulates and teachings (doctrine) and expert opinions which are systematically arranged as a composition of legal facts. 
The data analysis technique was carried out qualitatively, namely by collecting data, qualifying and then connecting theories related to the problem and drawing conclusions to determine the results. Data analysis is carried out by starting from research on the principles or principles as stipulated in the primary legal material, and then it will be discussed further using the means of the secondary legal material.

\section{Strengthening MSMEs for a Green Economy}

The development of economic digitization is a necessity in today's world economic development, so that the business world shifts from analog to virtual business. To encourage the economic development of MSMEs through the transformation of the use of information technology. President Joko Widodo said that digital transformation is the door for MSMEs to enter the marketplace, and can be part of a national or global supply chain. The momentum of the pandemic can be used to prepare MSMEs to advance to class. In line with existing data, recently there has been an increase in online sales transactions reaching 10-15 percent. Currently, there are 8 million of the 60 million MSME units connected to e-commerce and the development potential is very promising. Digital transformation helps people work faster and more efficiently and stay productive in the midst of limited interaction. The acceleration of digital transformation, starting from digital government, digital economy, to digital society, and digital infrastructure needs encouragement from the government (Farisa, 2021).

The magnitude of Indonesia's natural wealth should be able to make a major contribution to the progress of the nation based on economic, social and environmental balance - but the optimization of the management of the three helixes - green economy, social economy and financial economy - has not gone well. It is undeniable that the growth rate of Indonesia's GDP and controlled inflation in Indonesia continues to increase from year to year but the degradation of natural resources is also getting higher, as well as social inequality.

Green The green economy no longer invests in speculative securities such as hot papers, stocks, bonds and derivative products, but instead leads to clean and green investment that relies on clean technology to reduce carbon emissions. The green economy approach has begun to become a trend of economic policies carried out by developed countries. In contrast to Indonesia, the owner of the world's largest renewable natural resource potential - In addition to biodiversity, we also have the second longest coastline after Canada which can be a source of solar cell and wave power energy - not yet have a clear green economy concept through an integrated policy between all sectors and sub-sectors of Government.

The great potential in the green economy can guarantee the creation of jobs (pro jobs) and become the engine of the nation's economy that continues to grow sustainably (pro growth). For example: Indonesia has 19.5 million hectares of critical land (in forest areas) and 10.6 million hectares (outside forest areas). This critical land can be used to create environmentally friendly oil palm plantations, ethanol fuel, and organic agricultural land. Even the quality of bioethanol obtained from critical land is predicted to meet the daily fuel needs in Indonesia. The bioethanol produced is obtained from sources of corn, cassava, wheat, and sugar cane. How many local communities around this critical land will be absorbed if the green economy development is managed seriously, especially the people who are included in the MSME business (Panjaitan, 2010).

Social inequality can be measured based on the Gini ratio, which was still around 0.381 in March 2020. Nationally, the value of Indonesia's Gini Ratio during the period March 2013-September 2014 fluctuated and began to decline in the period March 2015 to September 2019. This condition indicates that during the March period 2015-March 2019 saw an improvement in the distribution of expenditure in Indonesia. However, due to the Covid-19 pandemic, the Gini Ratio value increased again in March 2020 Badan Pusat Statistik, 2020).

Pearce et al in Makmun said that failure in pragmatic and short-term development has the effect of environmental damage and the shrinking value of natural resources encourages every country to develop a green economy in order to develop a country's economy with low carbon, one of which is the development of ethanol and reducing the housing system. glass in accordance with the agreement of the United Nations organization - UNEP, the United Nation Environment Program which was founded in 1972 based in Nairoby, Kenya - has encouraged the implementation of the Green Economy Initiative (GEI) in 2008 (Makmun, 2011).

The Green Economy model is believed to be able to create green jobs and promote the concept of sustainable development, and be a way out for creating a clean and pollution-free environment, overcoming extractive resources through energy efficiency mechanisms and environmentally friendly products, and avoiding environmental degradation. Indonesia has the best biological natural resources in the world. The fact is that countries on the equator that have heavy rains and the sun shines throughout the year are very rich in biodiversity compared to countries with four seasons (Panjaitan, 2010).

Law cannot be separated from its habitat, so there is a continuous interaction between law and other factors, namely economic, social, cultural, political in the development of society. The failure of the law in the past (the New Order) to carry out its role in addition to the fact that the law always sided with the authorities, so solely to serve the continuity of power, also because the way of thinking used was more of a traditional legal approach pattern that emphasized the normative juridical aspect. Conventionally, these things cause the law to be trapped in rigid administrative corridors and the law to dry up because the law has been uprooted from its root habitat, namely its sociological elements (Sutrisno, 2005). 
Osneny, Mc Aucley in Suparji and Aris Machmud said that technological developments in various fields as a result of the development of the 4.0 era encourage increased applications in the field of financial inclusion (fintech - digital-based financial technology) or an economic industry designed by a company that uses technology so that the system more efficient finance (Suparji \& Machmud, 2019). Where this fintech has two conflicting sides, on the one hand it is a blessing where people who do not have access to banking can be served through the application, but on the one hand it causes many problems if the risks are not mitigated and can disrupt the financial system at a macro level. Fintech became known in the late 1900s and early 2000s where the first time with the concept of direct-to-consumer loans (peer to peer (P2P)) was initiated by Nepter and Zopa in the UK and in Indonesia developed in 2010 through the Go-Jek company.

The Islamic economy in technological development can be seen from the development of the sharia-based financial industry, this Fintech provides convenience for MSMEs and the public who have not been reached by banking services, considering the requirements are quite complicated, with this fintech financial inclusion can be served to remote corners of the country. Oseni Umar A. Ali S. Nazim in Suparji and Aris Machmud said that financial technology is also developing in the Islamic finance-based financial industry as follows so that a regulation is needed that can guarantee legal certainty and guarantee the development of the financial industry in particular: "Fintech is changing our lives for the better through unending technological applications in the finance industry. The daily lives of human beings, and even nonhumans, are now tied to technological applications where robots have taken over the roles of financial advisors. While regulators and lawmakers try to catch up with the rapid developments in financial technology, it appears the rapid rate of development in the fintech sector is outpacing regulatory frameworks. This uncertain situation is more complicated in a niche industry such as the Islamic financial services industry, which has additional faith-based filters in its productdevelopment process. This therefore makes a case for the need for thought leadership in relation to this uniquely important subject in order to guide policymakers, regulators, and practitioners on the dynamics of fintech in Islamic finance, and provide a good understanding of the Sharī'ah and legal and regulatory parameters for fintech solutions." For this reason, the Indonesian government through Bank Indonesia issued a regulation to fill the void in existing regulations (Ius Constituendum) by issuing Bank Indonesia Regulation Number 19/12/PBI 2017 concerning financial technology.

\section{MSMEs Pillars of the Welfare State}

JG Andersen in Elviandri, Khuzdaifah Dimyati, and Absori said that the welfare state is a state in which organized power is intentionally used (through political and administrative policies) in an effort to ensure the welfare of individuals and families to obtain a minimum income based on a decent life and guarantee the need for social services to the community. poor individuals and families, and guarantees all citizens to get their rights. The welfare state is closely related to policies concerning social policies, social protection policies and social security policies (both in the form of social assistance and social insurance), social safety nets policies (Elviandri \& Khuzdaifah Dimyati, 2019).

Bessant, Watts, Dalton and Smith in Oman Sukmana that the basic idea of the welfare state dates back to the 18th century, Jeremy Bentham - the father of welfare states - promotes the idea that the government has a responsibility to ensure the greatest happiness (or welfare) of the greatest number. of their citizens. Bentham uses the term 'utility' to describe the concept of happiness or wellbeing - Bentham argues that something that gives rise to extra happiness is something good. On the other hand, something that causes pain is bad, so government action should always be directed at increasing the happiness of as many people as possible.

The concept of a welfare state was pioneered by Otto Von Bismarck, according to Triwibowo \& Bahagio in Oman Sukman that in Europe and America, the idea of a welfare state had clashed with the concept of a capitalistic liberal state. produce prosperous countries, especially in Western Europe and North America, where people live in prosperity.

The welfare of a country is determined by the country's economic development, economic development will not be achieved without legal reform (Rajagukguk, 2003). The welfare state is associated with the fulfillment of basic needs - the fulfillment of social security, health, housing and education - which is a government policy that adheres to the welfare state. Economic growth in Indonesia is determined by the synergy and balance of development between the center and the regions, Java and outside Java. Invitations related to investment and autonomy are expected to encourage investment in the regions, so that employment opportunities can be opened again to solve the unemployment problem. However, economic actors need certainty to make economic decisions. Business people will always think the importance of certainty. In socialist countries, the welfare state also includes job security and the administration of prices for goods and services at the consumer level. The concept of the welfare state is therefore usually based on the principles of equality of opportunity, equitable distribution of wealth, and public responsibility for those who are unable to provide for themselves the minimum needs for a decent life. The term welfare state is very general and can include various forms of social and economic organization.

The welfare state has been given much attention by many parties because it is considered the most appropriate answer to the form of state involvement in advancing people's welfare. The Welfare State is assumed that the state has responsibility for guaranteeing a minimum standard of living for its citizens, in Indonesia as stated in the preamble to the 1945 Constitution of the Republic of Indonesia Article 27 (2), Article 28A, 28B, 28C, 28H, 31, 33, and Article 34.

Bessant, Watts, Dalton, Smith, Oman Sukmana in Aris Machmud that the basic idea of the welfare state dates back to the 18th century, Jeremy Bentham - the father of welfare states - promotes the idea that the government has a responsibility to ensure the 
greatest happiness (or welfare) of the greatest number of their citizens. Bentham uses the term 'utility' to describe the concept of happiness or well-being - Bentham argues that something that gives rise to extra happiness is something good. On the other hand, anything that causes pain is bad, so government action should always be directed at increasing the happiness of as many people as possible. The concept of a welfare state was pioneered by Otto Von Bismarck, according to Triwibowo \& Bahagio in Oman Sukman that in Europe and America, the idea of a welfare state had clashed with the concept of a capitalistic liberal state. produce prosperous countries, especially in Western Europe and North America, where people live in prosperity. Suharto and Husodo in Oman Sukmana argue that the welfare state can be defined as a social welfare system that gives the state (government) a greater role to allocate part of public funds to ensure the fulfillment of basic needs and the government is responsible for guaranteeing a minimum standard of welfare for every citizen. country (Sukmana, 2016).

TH Mashall in Oman Sukmana that the establishment of a welfare state is one of the essential pillars of a democratic state - a democratic state must present the fulfillment of social rights for each of its citizens, inherently as the responsibility of a democratic state - in line with the substantial democratic goal of providing fulfillment of living standards good social welfare, so that he can use his civil and political rights in full. The basic objective of promoting the principle of social rights is that citizens can fully actualize all their potential abilities and avoid the process of structural impoverishment. The philosophical idea of social justice is mainly related to distributive justice - the policy of the welfare state aims to distribute income fairly to all citizens, to ensure the worthiness of its citizens. To guarantee the right to a decent life for every citizen, it is necessary to have an active initiative and the responsibility of the government to maintain and realize the fulfillment of these social rights.

Even in the welfare state, the principle of the balance of public and economic authority and economic efficiency is carried out, where the free market cannot be left alone to regulate the complexities of public life. When the free market mechanism is allowed to run without restrictions and regulations, it actually widens the gap in social inequality, poverty and injustice, and destroys the basic foundations of public life that depart from the bonds of social relations. In contrast to the free market knowledge regime, the welfare state paradigm emphasizes the importance of the role of the state as a political authority acting as an agency that moves and regulates public life. The state is not anti-free market, but the role of the state is needed as a regulator so that it functions properly and does not marginalize common interests (Sukmana, 2016).

The Welfare State is the state's commitment to provide decent income to all its citizens without exception, avoiding unemployment or work incapacity due to illness, old age, basic health insurance services and adequate education guarantees, as Dorothy Wadderburn said: "The welfare state implies a state commitment of some degree which modifies the play of wealth in order to ensure a minimum real income for all. By implication, if not explicitly, this is done to protect individuals against the hazards of incapacity for work arising through sickness, old age, and unemployment. There is also a general agreement that the objectives of the welfare state will include a guarantee of treatment and benefit for sickness and injury, and the provision of education”(Dorothy Wedderburn, 1965).

\section{Conclusion}

The welfare of the people is achieved through economic and economic development depending on the roles of the legal functions "stability", "predictability" and "fairness". The welfare state is achieved through the development of laws that protect the weak because the state protects the interests and basic needs of its citizens. MSMEs are the driving force of the people's economy that are not accommodated in the formal sector - and consumer protection and protection of the environment besides that there is a need for legal reform if it is suspected that there is still neglect of weak rights. A democratic country, with a fairly explicit commitment to broad goals of economic development, full employment, equal opportunity for youth, social security, and protected minimum standards not only in terms of income, but also nutrition, housing, health and education, for people from all regions and social groups.

In order to increase efficiency and effectiveness in creating an investment climate towards a green economy, in the era of free markets, the government as the authority holder, must be able to create a conducive business climate. Conducive conditions will help SMEs to develop their business in a better direction. A safe and peaceful situation coupled with real support from the Government and elements of society is a very important capital for the development of the business climate in Indonesia. Aspects that create a business climate are funding, infrastructure, business information, partnerships, business legalization, business opportunities, trade promotions, institutions and health. The government is expected to expand sources and access to funding and provide convenience in funding for MSMEs. So that MSMEs can get the opportunity to enjoy these facilities to develop their business.

\section{References}

Alfitri. (2012). Ideologi Welfare State dalam Dasar Negara Indonesia: Analisis Putusan Mahkamah Konstitusi Terkait Sistem Jaminan Sosial Nasional. Jurnal Konstitus, 9(3), 450-472. https://doi.org/10.31078/jk\%25x

Azis, M. H. M. (2018). Pembangunan Ekonomi \& Pemberdayaan Masyarakat. Makassar, CV. Nur Lina.

Badan Pusat Statstik. (2020). Gini Ratio Maret 2020 tercatat sebesar 0,381. Retrieved from https://www.bps.go.id/pressrelease/2020/07/15/1748/gini-ratio-maret-2020-tercatat-sebesar-0-381.html

Elviandri \& Khuzdaifah Dimyati, A. (2019). Quo Vadis Negara Kesejahteraan: Meneguhkan Ideologi Welfare State Negara Hukum Kesejahteraan Indonesia. Mimbar Hukum, 31(2), 252-266. Available on https://jurnal.ugm.ac.id/jmh/article/download/32986/25629 
Farisa, F. C. (2021). Jokowi Sebut Transformasi Digital Pintu Masuk UMKM ke. “Marketplace”. Accessed on 26 February 2021. Retrieved from https://nasional.kompas.com/read/2021/02/26/16523401/jokowi-sebut-transformasi-digital-pintu-masukumkm-ke-marketplace?page=all

Hartomo, G. (2020). Terkuak, Ini Kontribusi UMKM bagi Perekonomian Indonesia. Accessed on 26 February 2021. Retrieved from https://economy.okezone.com/read/2020/10/20/455/2296549/terkuak-ini-kontribusi-umkm-bagi-perekonomian-indonesia

Kurniawan, L.J., Sukmana, O. and Abdussalam, M. (2015). Negara Kesejahteraan dan Pelayanan Sosial: Kebijakan sosial dan Pekerjaan Sosial dalam Penyelenggaraan Jaminan Perlindungan Warga Negara. Malang, instrans Publishing.

Makmun. (2011). Green Economy: Konsep, Implementasi, dan Peran Kementrian Keuangan. Retrieved from https://media.neliti.com/media/publications/77730-ID-green-economy-konsep-impelentasi-dan-per.pdf

Orosz, Á. (2017). Development Of Welfare State Theory: A Review of The Literature. PRO PUBLICO BONO - Magyar Közigazgatás, 2, 176-191. http://real.mtak.hu/89368/1/10-Development-of-Welfare-State_PPB_2017_220web-10.pdf

Panjaitan, L. T. (2010). Saatnya Green Economy, Indonessia. Accessed on 26 February 2021. Retrieved from https://news.detik.com/opini/d-1401687/saatnya-green-economy-indonesia

Rajagukguk, E. (2003). Hukum Ekonomi Indonesia Memperkuat Persatuan Nasional, Mendorong Pertumbuhan Ekonomi dan Memperluas Kesejahteraan Sosial. Presented at the VIII National Law Development Seminar and Workshop, organized by the National Legal Development Agency, Ministry of Justice and Human Rights, Denpasar 14-18 July 2003. Retreved from https://adoc.pub/hukum-ekonomi-indonesia-memperkuat-persatuan-nasional-mendor.html

Soesilo, H. I. (2007). Stratedi UMKM dalam Mengatasi Sistem Prosedur Kredit komersial. Jurnal Development, (1), 1-14. Retrieved from http://jurnal.umjambi.ac.id/index.php/JD/article/download/39/39/

Sukmana, O. (2016). Konsep dan Desain Negara Kesejahteraan ( Welfare State ). Sospol: Jurnal Sosial Politik, 2(1), $103-122$. https://doi.org/10.22219/sospol.v2i1.4759

Suparji, A. \& Machmud, A. (2019). Application Of Regulation And Completion Of Fintech Dispute In Legal Certainty. the 3rd international conference on Islamic epistemology, 8 October 2019. Jakarta, Center for Islamic Integration on Scientific Paradigm, University of Al-Azhar Indonesia.

Suparji. (2020). Implementation of Intellectual Property Right to Strengthen Small and Medium-Sized Enterprise Business Capacity in Global Competition. Academic Journal of Interdiciplinary Studies, 9(6), $139-147$. https://doi.org/10.36941/ajis.2020.v9n6r

Sutrisno, E. (2005). Mengukuhkan Paradigma Hukum Di Era Orde Reformasi. "Syarıah" Jurnal Ilmıah Fakultas Hukum Unıversitas Swadaya Gunung Jat1, 1(1), 1-12. Retrieved from http://jurnal.ugj.ac.id/index.php/SYARIAH/article/view/1160/737

Wedderburn. D. (1965). Fact And Theories Of The Welfare State. The Socialist Register, 2, 127-146. Available on https://socialistregister.com/index.php/srv/article/view/5952/2848

Publisher's Note: SSBFNET stays neutral with regard to jurisdictional claims in published maps and institutional affiliations.

\section{(c) (1)}

(C) 2021 by the authors. Licensee SSBFNET, Istanbul, Turkey. This article is an open access article distributed under the terms and conditions of the Creative Commons Attribution (CC BY) license (http://creativecommons.org/licenses/by/4.0/).

International Journal of Research in Business and Social Science (2147-4478) by SSBFNET is licensed under a Creative Commons Attribution 4.0 International License. 